\title{
Periapical Repair after Root Canal Filling with Different Root Canal Sealers
}

\author{
Mário TANOMARU-FILHO ${ }^{1}$ \\ Juliane Maria Guerreiro TANOMARU1 \\ Mario Roberto LEONARDO ${ }^{1}$ \\ Lea Assed Bezerra da SILVA ${ }^{2}$ \\ ${ }^{1}$ Department of Restorative Dentistry, Araraquara Dental School, São Paulo State University, Araraquara, SP, Brazil \\ ${ }^{2}$ Department of Pediatric Clinic, Preventive and Community Dentistry, Ribeirão Preto Dental School, \\ University of São Paulo, Ribeirão Preto, SP, Brazil
}

\begin{abstract}
The aim of this study was to evaluate periapical repair after root canal filling with different endodontic sealers. Sixty-four root canals from dog's teeth were filled, divided into 4 groups $(n=16)$. Root canals were instrumented with K-type files and irrigated with $1 \%$ sodium hypochlorite solution. Root canals were filled in the same session by active lateral condensation of the cones and sealers: Intrafill, AH Plus, Roeko Seal and Resilon/Epiphany System. After 90 days, the animals were euthanized and the tissues to be evaluated were processed and stained with hematoxylin and eosin. For histopathological analysis, the following parameters were evaluated: inflammatory process, mineralized tissue resorption, and apical mineralized tissue deposition. Histopathological analysis demonstrated that Intrafill had less favorable results in terms of apical and periapical repair, compared to the other sealers ( $<<0.05)$. AH Plus, Roeko Seal, and Epiphany sealers had similar and satisfactory results $(\mathrm{p}>0.05)$. In conclusion, AH Plus and the materials Roeko Seal and Epiphany are good options for clinical use in Endodontics.
\end{abstract}

Key Words: Endodontics, histopathological evaluation, inflammation, root canal filling material.

\section{INTRODUCTION}

One of the goals of endodontic therapy is to allow apical and periapical repair. Endodontics is still searching for the ideal root canal filling material, which should have certain physical, chemical and biological properties (1).

Zinc oxide and eugenol-based sealers are used worldwide. However, their biological properties are not satisfactory (2), since they induce the presence of chronic periapical inflammatory infiltrate (3) that may persist for long periods of time (4).

Regarding epoxy resin-based sealers, AH Plus stands out due to its excellent biological properties (5). Leonardo et al. (5) histologically evaluated the response of apical and periapical tissues of dog teeth after pulpectomy and were able to demonstrate hard tissue formation in the periapical region when AH Plus sealer was used.

The silicone-based material Roeko Seal (Roeko,
Langenau, Germany) has shown good physical-chemical properties, such as adequate flowability (6) and low occurrence of apical infiltration $(7,8)$. Moreover, this sealer has low cytotoxicity $(9,10)$. Huumonen et al. (11) evaluated radiographically the apical repair process in human teeth sealed with Grossman and Roeko Seal Automix sealers. One-hundred and ninety-nine teeth with apical lesions were sealed and radiographically evaluated 3 and 12 months after root canal filling. The authors highlighted the lack of significant difference between the 2 evaluated sealers.

Resilon (Resilon Research LLC, Madison, CT, USA) is a root canal filling material based on a thermoplastic synthetic polymer with properties similar to gutta-percha, and is used in association with Ephiphany (Pentron Clinical Technologies, Wallingford, CT, USA), a methacrylate-based material. When Epiphany is used with Resilon, there is a strong bond between the dentin walls and the root canal filling material, increasing the

Correspondence: Mário Tanomaru Filho, Rua Humaitá, 1680, Centro, Caixa Postal 331, 14801-903 Araraquara, SP, Brasil. Tel: +55-16-3301-6390. Fax:+55-16-3301-6392. e-mail: tanomaru@uol.com.br 
resistance to bacterial penetration (12).

Several authors have studied the Resilon/Epiphany system $(13,14)$. Onay et al. (14) evaluated in vivo the biocompatibility of Resilon, gutta-percha, and Epiphany after implantation of samples in rat connective tissue. After 1, 4, and 8 weeks, samples were removed. The authors concluded that all the materials tested presented acceptable biocompatibility. Souza et al. (15) evaluated the intraosseous biocompatibility of AH Plus, EndoREZ, and Epiphany in Guinea pigs, observing that AH Plus promoted moderate to severe response, while with Epiphany bone formation was observed, accompanied by mild or no inflammatory response. When the biocompatibility of Sealapex was compared with Epiphany sealer, Leonardo et al. (16) observed that, after root canal filling in dog teeth, Epiphany showed better results in the histological analysis compared to Sealapex.

New clinical studies became necessary to evaluate the biological properties of Roeko Seal and of the Resilon/Epiphany system in experimental animal models, especially studies that involve histopathological analysis. Accordingly, the present study aims to assess the biological properties of these materials, by evaluating the periapical repair after root canal filling in dog teeth.

\section{MATERIAL AND METHODS}

Four mongrel dogs, approximately one year old, were utilized in this study. The teeth selected were the second, third, and fourth mandibular premolars and the second and third maxillary premolars, totalling 64 roots, which were divided in 4 experimental groups. The experimental procedures were in accordance with the Institutional Committee of Animal Experimentation and the International Guiding Principles for Biological Research Involving Animals (Geneva, 1985).

The animals were anesthetized intravenously with sodium thiopental (Thionembutal; Abbott Laboratórios do Brasil Ltda., Rio de Janeiro, RJ, Brazil). All materials were tested in each animal, and the experimental protocols were performed in alternate quadrants in a randomized manner. Root canals were filled with the following materials: Intrafill (Dentsply Ind. e Com. Ltda., Petrópolis, RJ, Brazil, batch 691100), AH Plus (Dentsply De Trey GmbH, Konstanz, Germany, batch 0707001828); Roeko Seal (RSA RoekoSeal Single dose; Roeko, batch 002,2004-09); Resilon/Epiphany (Pentron Clinical Technologies, batch 143930). Each experimental group included 16 roots.

After isolation of the teeth with a rubber dam and disinfection of the operative field with $2 \%$ gluconate chlorhexidine, access to the pulp chambers were made. The working length was determined to be $2 \mathrm{~mm}$ short of the radiographic apex using \#25 K-type files (Dentsply/ Maillefer, Ballaigues, Switzerland). The pulp tissue was removed, and the root canals were irrigated with $2 \mathrm{~mL}$ of $1 \%$ sodium hypochlorite solution.

The apical cementum layer was then perforated with the sequential use of \#15 to \#30 K-files, thus creating standardized apical foramen openings. Thereafter, the root canals were instrumented to the working length up to \#60 K-file under irrigation with $1 \%$ sodium hypochlorite solution at each instrument change. A \#30 K-file was taken to the total root length to ensure apical patency. After final irrigation with sodium hypochlorite, the root canals were dried with sterile paper points and then filled with 14.3\% EDTA (Odahcan-Herpo, Prod. Dent. Ltda., Rio de Janeiro, RJ, Brazil) for 3 min. Sterile saline was used to rinse out the EDTA, and the root canals were then dried with sterile paper points.

The canals were filled by lateral condensation of gutta-percha and one of the sealers. The sealers were taken the root canals using a \#50 K-file up to the working length. For the teeth filled with Resilon/Epiphany, the primer was first applied to the root canal walls with sterile paper points and then, obturation was done by lateral condensation of the Resilon cones. In all groups, the coronal access preparations were restored with a glass ionomer cement base (Vitremer; 3M/ESPE, St. Paul, MN, USA) and silver amalgam (Velvalloy; S.S. White Artigos Dentários Ltda., Rio de Janeiro, RJ, Brazil).

After a 90-day experimental period, the animals were euthanized with an intravenous overdose of sodium pentobarbital. The maxillas and mandibles were dissected and sectioned to obtain individual roots that were fixed in sodium cacodylate solution with added sucrose and glutaraldehyde (17). The specimens were then washed and demineralized with an EDTA-based solution. Six-micrometer-thick serial sections (25-30 sections per specimen were obtained and stained with hematoxylin-eosin (HE) and Mallory trichrome. The sections were examined under optical microscopy by two calibrated examiners blinded to the treatment of each group. In case of disagreement, the specimen was re-evaluated and a consensus was reached between the examiners. Scores of A, B, C or D. from best to worst, 
were given to each of the following parameters $(16,17)$ : Intensity and extension of the inflammatory infiltrate, periodontal ligament thickness, bone and apical cementum resorption, and apical opening sealing (Table 1).

The intensity of periapical inflammatory infiltrate was evaluated by counting the number of inflammatory cells in all specimens using the Image Pro Plus v. 6.1 software (Media Cybernetics, Silver Spring, USA). The medians (50\%) and quartiles (25\% and $75 \%$ ) were calculated and the values were distributed in 4 intervals. These values were used to establish intervals corresponding to scores A to D (Table 1). The apical periodontal ligament thickness was evaluated according to the distance (in $\mathrm{mm}$ ) between the apical surface and the bone tissue, using the Image Pro Plus v. 6.1 software (Media Cybernetics). The medians (50\%) and quartiles (25\% and $75 \%$ ) were calculated and the values were distributed in 4 intervals. These values were used to establish intervals corresponding to scores A to D (Table 1).

Results were calculated by adding the values of all histopathological parameters in each group and then comparing the groups. Statistical analysis was done with the nonparametric Kruskal-Wallis test and the 2-by-2 comparisons of the Dunn's method $(\mathrm{p}<0.05)$.

\section{RESULTS}

Significant difference between Intrafill, a zinc oxide and eugenol-based material) and the other materials $(p<0.05)$ was detected. General analysis of the

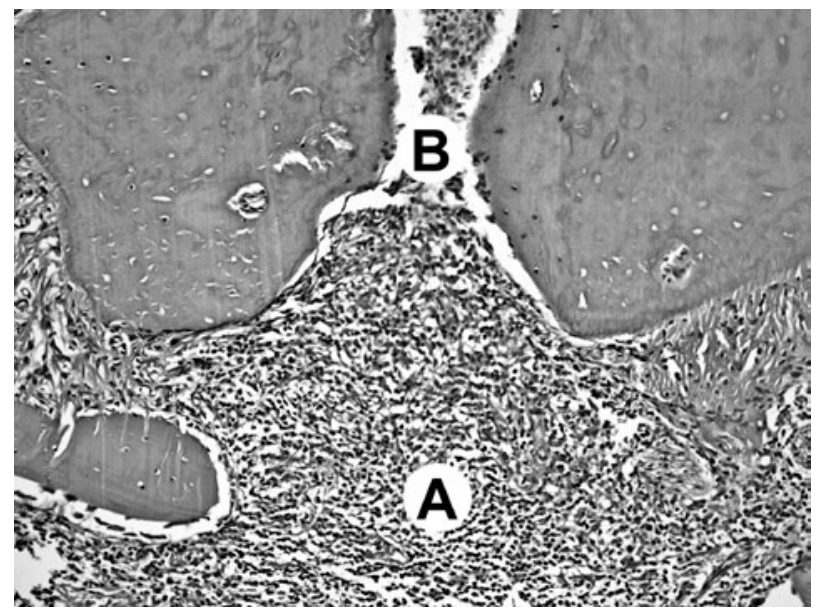

Figure 1. Intrafill. Periapical area with inflammatory cell infiltrate (A) and no apical seal (B). HE (original magnification $\times 100$ ). histopathological parameters demonstrated that Intrafill presented less favorable results in terms of periapical repair compared to the other materials $(\mathrm{p}<0.05)$. AH Plus, Roeko Seal and Resilon/Epiphany had similar periapical repair $(\mathrm{p}>0.05)$, and all showed consistently more favorable results than Intrafill $(p<0.05)$. The results of the qualitative analysis for the tested materials are described in the following paragraphs.

\section{Intrafill}

Inflammatory cell count demonstrated the presence of severe/intense inflammatory reaction in most specimens evaluated in this group. Measurement of the apical periodontal space and assignment of scores demonstrated that in this group, the periodontium was intensely/severely thickened (Fig. 1).

\section{AH Plus}

The periapical inflammatory reaction in this group was less intense than that observed for Intrafill $(\mathrm{p}<0.05)$ (Fig. 2). Inflammatory cell count in the 16 cases in this group showed that 12 specimens had score

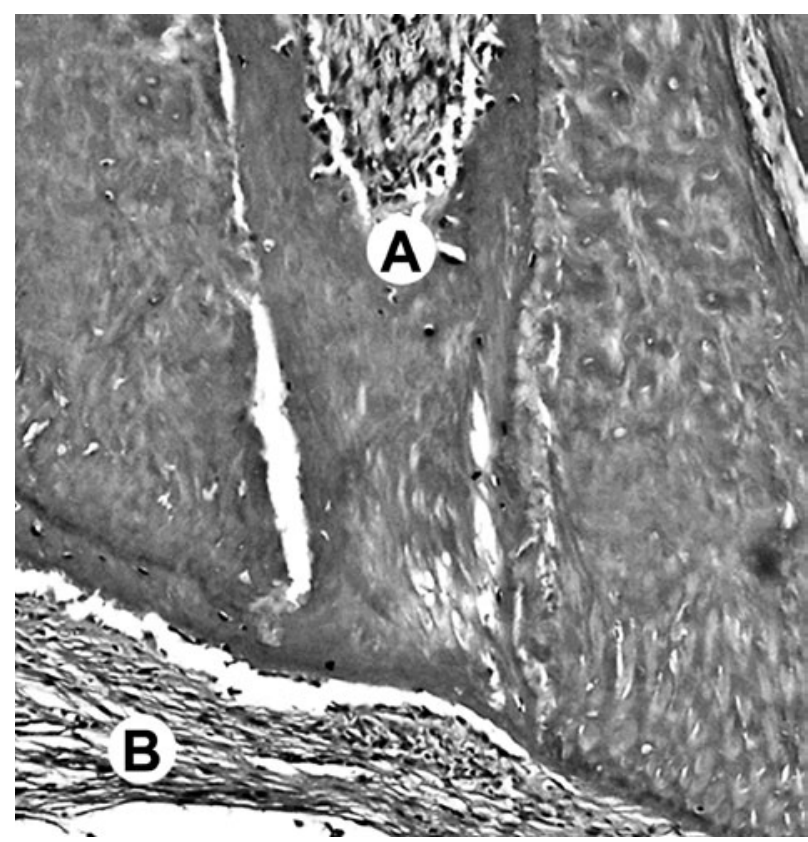

Figure 2. AH Plus. Image of the apex showing partial biological seal by deposition of mineralized tissue (A) and mild inflammatory cell infiltrate $(B)$. HE (original magnification $\times 100$ ). 
of A or B. The periapical periodontium was slightly or moderately thickened.

\section{Roeko Seal}

The degree of periapical inflammation was similar to that observed for AH Plus (Fig. 3). Inflammatory cell count showed that the cases in this group $(n=16)$ had predominant scores of A or B. Apical foramen sealing was observed in most of the cases.

\section{Resilon/Epiphany}

Periapical inflammatory response was similar

Table 1. Frequency of scores corresponding to each histopathological parameter for the ested materials.

\begin{tabular}{|c|c|c|c|c|c|}
\hline $\begin{array}{l}\text { Histological } \\
\text { parameter }\end{array}$ & Scores & $\begin{array}{l}\text { Intrafill } \\
(\mathrm{n}=16)\end{array}$ & $\begin{array}{l}\text { AH Plus } \\
(\mathrm{n}=16)\end{array}$ & $\begin{array}{l}\text { RoekoSeal } \\
\quad(\mathrm{n}=16)\end{array}$ & $\begin{array}{l}\text { Epiphany/Resilon } \\
\qquad(\mathrm{n}=16)\end{array}$ \\
\hline \multirow{4}{*}{$\begin{array}{l}\text { Inflammatory } \\
\text { infiltrate } \\
\text { intension }\end{array}$} & $\mathrm{A}=$ From 0 to 7 inflammatory cells & - & 6 & 5 & 5 \\
\hline & $\mathrm{B}=$ From 7.1 to 8 inflammatory cells & 1 & 6 & 6 & 5 \\
\hline & $\mathrm{C}=$ From 8.1 to 8.6 inflammatory cells & 5 & 2 & 4 & 4 \\
\hline & $\mathrm{D}=$ More than 8.7 inflammatory cells & 10 & 2 & 1 & 2 \\
\hline \multirow{5}{*}{$\begin{array}{l}\text { Periodontal } \\
\text { ligament } \\
\text { thickness }\end{array}$} & $\mathrm{A}=$ From 0 to $0.21 \mathrm{~mm}$ & - & 6 & 6 & 5 \\
\hline & $\mathrm{B}=$ From 0.22 to $0.26 \mathrm{~mm}$ & - & 4 & 7 & 7 \\
\hline & $\mathrm{C}=$ From 0.27 to $0.28 \mathrm{~mm}$ & 4 & 4 & 2 & 3 \\
\hline & $\mathrm{D}=$ Greater than $0.29 \mathrm{~mm}$ & 12 & 2 & 1 & 1 \\
\hline & $\mathrm{A}=\mathrm{Absent}$ & 10 & 15 & 14 & 14 \\
\hline \multirow{3}{*}{$\begin{array}{l}\text { Bone } \\
\text { resorption }\end{array}$} & $\mathrm{B}=\mathrm{Few}$ areas of bone repair & 4 & 1 & 2 & 2 \\
\hline & $\mathrm{C}=$ Small active areas & 2 & - & - & - \\
\hline & $\mathrm{D}=$ Large active areas & & & & \\
\hline \multirow{4}{*}{$\begin{array}{l}\text { Inflammatory } \\
\text { infiltrate } \\
\text { extension }\end{array}$} & $\mathrm{A}=\mathrm{Absent}$ & - & - & - & - \\
\hline & $\mathrm{B}=$ Restricted to the apical foramen & - & 4 & 3 & 3 \\
\hline & $\mathrm{C}=\mathrm{Up}$ to $1 / 2$ of the apical periodontal space (APS) & 9 & 10 & 13 & 11 \\
\hline & $\mathrm{D}=$ More than $1 / 2$ of the APS & 7 & 2 & - & 2 \\
\hline \multirow{4}{*}{$\begin{array}{l}\text { Apical } \\
\text { cementum } \\
\text { resorption }\end{array}$} & $A=A b s e n t$ & 12 & 16 & 16 & 16 \\
\hline & $\mathrm{B}=$ Affecting up to $1 / 2$ of cementum thickness & 4 & - & - & - \\
\hline & $\mathrm{C}=$ More than $1 / 2$ of cementum thickness & - & - & - & - \\
\hline & $\mathrm{D}=$ Reaching dentin & & & & \\
\hline \multirow{4}{*}{$\begin{array}{l}\text { Apical } \\
\text { opening } \\
\text { sealing }\end{array}$} & $\mathrm{A}=$ Complete apical sealing & - & - & 1 & - \\
\hline & $B=$ More than $1 / 2$ of the apical foramen & - & 6 & 4 & 5 \\
\hline & $\mathrm{C}=\mathrm{Up}$ to $1 / 2$ of the apical foramen & 10 & 10 & 11 & 11 \\
\hline & $\mathrm{D}=\mathrm{Absent}$ & 6 & - & - & - \\
\hline
\end{tabular}


to that detected for AH Plus and Roeko Seal $(\mathrm{p}>0.05)$ (Fig. 4). The periapical periodontium showed, in most cases, mild or moderate thickening. Mineralized tissue deposition at the apical foramen was observed.

\section{DISCUSSION}

Comparative analysis of the histopathological results demonstrated better tissue repair when $\mathrm{AH}$ Plus, Roeko Seal, and the Resilon/Epiphany System were used. These experimental groups presented high frequency of partial biological sealing of the apices, predominance of mild or moderate inflammatory infiltrate, and no areas of cementum and bone resorption.

A zinc oxide and eugenol-based sealer was used as a control because this material is known to induce chronic periapical inflammatory infiltrate $(3,18)$. In the specimens where Intrafill (zinc oxide and eugenol-based material) was used, intense/severe periapical inflammatory infiltrate was observed. Deposition of mineralized tissue at the apex occurred in a few cases and only partially covered the apical foramen. The results for this zinc oxide and eugenol-based sealer are in agreement with Leonardo et al. (2), who reported unsatisfactory periapical repair when Fill Canal (another zinc oxide and eugenol-based material) was used in root canal fillings in dog teeth.

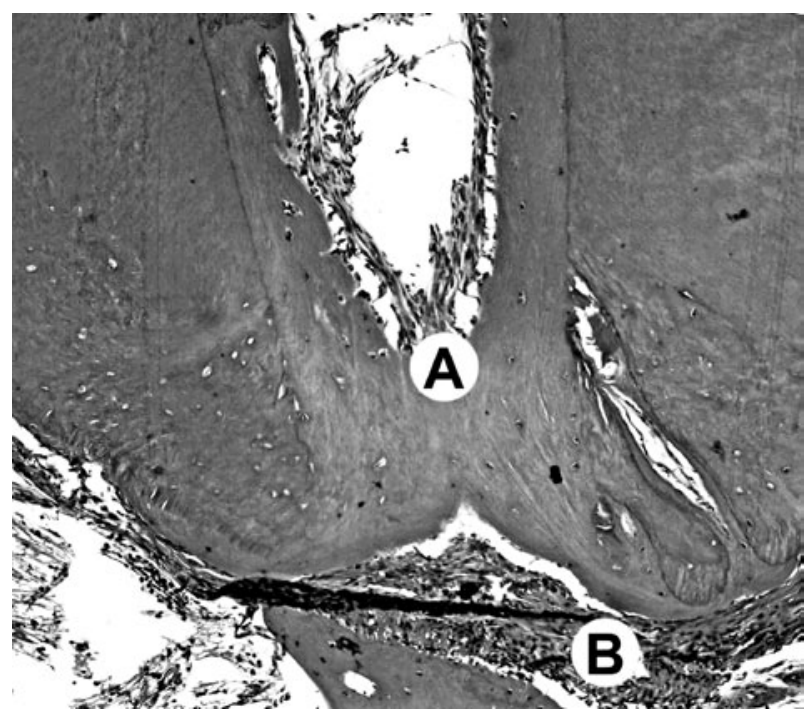

Figure 3. RoekoSeal. Image of the apex showing partial biological seal by deposition of mineralized tissue (A) and mild inflammatory cell infiltrate $(\mathrm{B})$. HE (original magnification $\times 100$ ).
The biocompatibility of AH Plus confirms previous results from Leonardo et al. (5), evaluated the performance of this material in dog teeth after pulpectomy reporting no inflammatory cells or areas of necrosis associated with AH Plus. They observed hard tissue formation with AH Plus in most of the specimens, and inflammatory response adjacent to the zinc-oxide and eugenol sealer.

These favorable results were supported by detection of only mild/slight periapical inflammatory infiltrate, along with deposition of mineralized tissue at the apex, which covered up to half or more than half of the apical foramen in the majority of cases. The favorable results of periapical healing obtained after root canal filling with AH Plus (5) allow using this material as parameter for comparison with new filling materials.

Acceptable results in terms of apical and periapical repair have also been observed for the Resilon/ Epiphany System. Our results showed mineralized tissue deposition at the apical foramen in all teeth, and in most cases the mineralized tissue covered more than half of the foramen.

Shipper et al. (19), evaluated periapical tissues of dog teeth filled with gutta-percha and AH 26 or

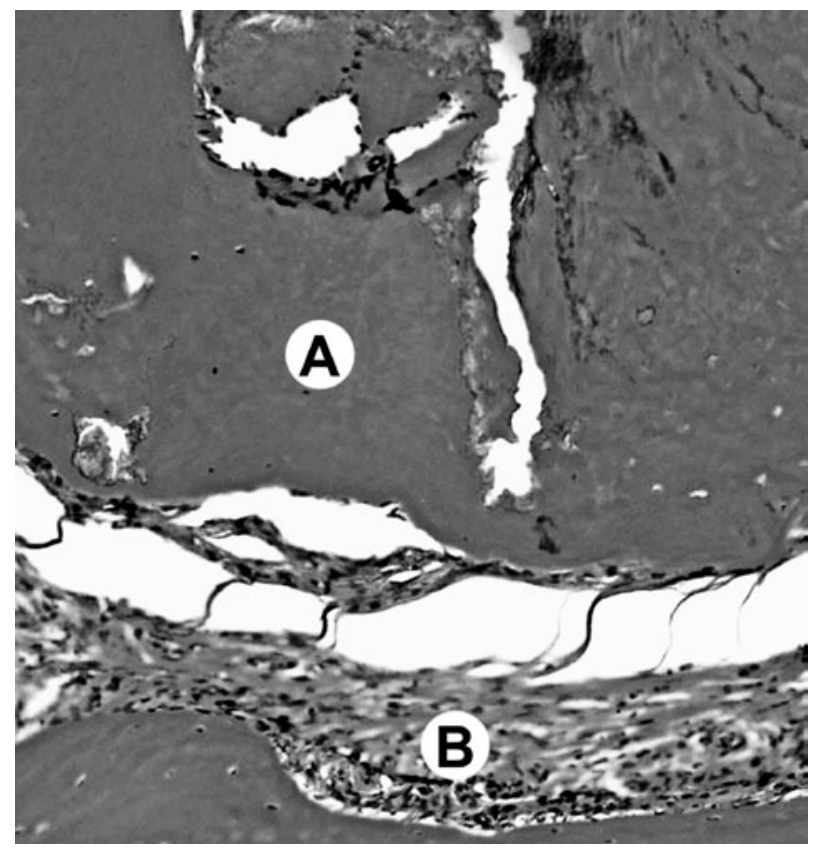

Figure 4. Epiphany/Resilon. Partial biological seal by deposition of mineralized tissue (A) and periapical area with mild inflammatory cell infiltrate (B). HE (original magnification $\times 200$ ). 
with the Resilon/Epiphany System, finding periapical inflammation in $82 \%$ of the teeth filled with $\mathrm{AH} 26$ and gutta-percha, and in only $19 \%$ of the cases where Resilon/Epiphany was used.

Souza et al. (15) evaluated the intraosseous biocompatibility of AH Plus, EndoREZ, and Epiphany in Guinea pigs, and observed new bone formation when Epiphany was used, along with mild or no inflammatory response. Leonardo et al. (16) studied in vivo the biocompatibility of Sealapex and of the Resilon/Epiphany System in endodontically treated dog teeth. The results showed that roots canals filled with Epiphany/Resilon, with coronal restoration, had significantly less periradicular inflammation and more biological apical sealing than roots canals filled with gutta percha and Sealapex.

Epiphany sealer has calcium hydroxide and may release calcium and hydroxyl ions contributing to its biocompatibility. Rezende et al. (20) observed that the solubility of Epiphany was greater than other sealers, with higher amounts of calcium ion release.

Roeko Seal, a silicone-based sealer, induced periapical repair, with results similar to AH Plus and Epiphany. The inflammatory infiltrate detected in the specimens where Roeko Seal was used was predominantly slight/mild. Favorable results were also observed in terms of periapical repair: deposition of mineralized tissue at the apical foramen was detected and covered half or more than half of the foramen in the majority of teeth, in addition to one case of complete seal.

Silicone is a biocompatible material, which may explain the good results obtained with Roeko Seal. Lodiene et al. (10) performed a cytotoxicity study in which Epiphany root canal sealer was significantly more toxic to L-929 cells than the silicone-based Roeko Seal and the single methacrylate-based EndoREZ root canal sealers. Miletic et al. (9) evaluated the cytotoxicity of endodontic sealers at $1 \mathrm{~h}, 24 \mathrm{~h}, 48 \mathrm{~h}, 1$ week, and 1 month after their manipulation, and reported that Roeko Seal did not present cytotoxic effects in any of the periods evaluated.

According to the present study, the Resilon/ Epiphany System, the silicone-based product Roeko Seal, as well as the AH Plus sealer presented good results in terms of periapical repair. Based on this biological property, it can be suggested that these materials are adequate choices for clinical application.

\section{RESUMO}

O objetivo deste estudo foi avaliar o reparo periapical após obturação de canal radicular usando os cimentos Roeko Seal e Epiphany. Sessenta e quatro canais radiculares de dentes de cães foram obturados, divididos em 4 grupos $(n=16)$. Os canais radiculares foram instrumentados com limas tipo $\mathrm{K}$ e irrigados com solução de hipoclorito de sódio a $1 \%$. Os canais radiculares foram obturados na mesma sessão usando condensação lateral ativa dos cones e os cimentos: Grupo I - Intra Fill; Grupo II AH Plus; Grupo III - Roeko Seal e Grupo IV - Sistema Resilon/ Epiphany. Após 90 dias, os animais foram mortos e os tecidos a serem avaliados foram processados e corados por hematoxilina e eosina. Para análise histopatológica, os seguintes parâmetros foram avaliados: processo inflamatório, reabsorção dos tecidos mineralizados e deposição de tecido mineralizado apical. A análise histopatológica demonstrou que o Intrafill teve resultados menos favoráveis em relação ao reparo apical e periapical comparado aos outros cimentos $(\mathrm{p}<0,05)$. AH Plus, Roeko Seal e Epiphany demonstraram resultados similares e satisfatórios $(p>0,05)$. Conclui-se que o AH Plus e os materiais Roeko Seal e Epiphany são boas opções para uso clínico em endodontia.

\section{ACNOWLEGDMENTS}

This study was supported by grants from the São Paulo State Research Foundation (FAPESP - grant \#05/51433-8).

\section{REFERENCES}

1. Eldeniz AU, Mustafá K, Orstavik D, Dahl JE. Cytotoxicity of new resin-, calcium hydroxide-, and silicon-based root canal sealers on fibroblasts derived from human gingiva and L929 cell lines. Int Endod J 2007;40:329-337.

2. Leonardo MR, Almeida WA, Silva LAB, Utrilla LS. Histological evaluation of the response of apical tissues to glass ionomer and zinc oxide-eugenol based sealers in dog teeth after root canal treatment. Endod Dent Traumatol 1998;14:257-261.

3. Tanomaru Filho M, Leonardo MR, Silva LA, Utrilla LS. Effect of different root canal sealers on periapical repair of teeth with chronic periradicular periodontitis. Int Endod J 1998;31:85-89.

4. Yesilsoy C, Koren LZ, Morse DR, Kobayashi C. A comparative tissue toxicity evaluation of established and newer root canal sealers. Oral Surg Oral Med Oral Pathol 1988;65:459-467.

5. Leonardo MR, Almeida WA, Silva LAB, Utrilla LS. Tissue response to an epoxy resin-based root canal sealer. Endod Dent Traumatol 1999;15:28-32.

6. Testarelli L, Andreasi-Bassi M, Gambarini G. In vitro evaluation of five root canal sealers. Minerva Stomatol 2003;52:19-24.

7. Cobankara FK, Adanir N, Belli S, Pashley LH. A quantitative evaluation of apical leakage of four root-canal sealers. Int Endod J 2002;35:979-984.

8. Wu MK, Van Der Sluis LW, Wesselink PR. A 1-year follow-up study on leakage of single-cone fillings with RoekoRSA sealer. Oral Surg Oral Med Oral Pathol Oral Radiol Endod 2006;101:662667.

9. Miletic I, Devcic N, Anic I, Borsic J, Karlovic Z, Osmak M. The cytotoxicity of RoekoSeal and AH plus compared during different setting periods. J Endod 2005;31:307-309.

10. Lodiene G, Morisbak E, Bruzell E, Orstavik D. Toxicity evaluation of root canal sealers in vitro. Int Endod J 2008;41:72-77. 
11. Huumonen S, Lenander-Lumikari M, Sigurdsson A, Orstavik D Healing of apical periodontitis after endodontic treatment: a comparison between a silicone-based and a zinc oxide-eugenol-based sealer. Int Endod J 2003;36:296-301.

12. Shipper G, Teixeira FB, Arnold RR, Trope. An evaluation of microbial leakage in roots filled with a thermoplastic synthetic polymer-based root canal filling material (Resilon). J Endod 2004;30:341-347.

13. Barbizan JV, Trope M, Teixeira EC, Tanomaru-Filho M, Teixeira FB. Effect of calcium hydroxide intracanal dressing on the bond strength of a resin-based endodontic sealer. Braz Dent J 2008; 19:224-227.

14. Onay EO, Ungor M, Ozdemir BH. In vivo evaluation of the biocompatibility of a new-resin based obturation system. Oral Surg Oral Med Oral Pathol Oral Radiol Endod 2007;104:60-66.

15. Sousa CJ, Montes CR, Pascon EA, Loyola AM, Versiani MA. Comparison of the intraosseous biocompatibility of AH Plus, EndoREZ, and Epiphany root canal sealers. J Endod 2006;32:656662.

16. Leonardo MR, Barnett F, Debelian GF, de Pontes Lima RK, Bezerra da Silva LA. Root canal adhesive filling in dog's teeth with or without coronal restoration: a histopathological evaluation. J Endod 2007;33:1299-1303.

17. Tanomaru JMG, Leonardo MR, Silva LAB, Poliseli-Neto A Tanomaru-Filho M. Histopathological evaluation of methods of experimental induction of periapical periodontitis. Braz Dent J 2008;19:238-244.

18. Holland R, Santa'Anna Junior A, Souza V, Dezan Junior E, Otoboni Filho JA, Bernabé PF, et al.. Influence of apical patency and filling material on healing process of dogs'teeth with vital pulp after root canal therapy. Braz Dent J 2005;16:9-16.

19. Shipper G, Orstavik D, Teixeira FB, Trope M. Periapical inflammation after coronal microbial inoculation of dog roots filled with gutta-percha or Resilon. J Endod 2005;31:91-96.

20. Rezende LM, Rached-Júnior FJ, Versiani MA, Souza Gabriel AE, Miranda CE, Silva-Souza YT, Souza Neto MD. A comparative study of physicochemical properties of AH Plus, Epiphany, and Epiphany SE root canal sealers. Int Endod J 2009;42:789-793.

Accepted October 21, 2009 